Review

\title{
Ultrasonography in Sheep Follicular Dynamics
}

\author{
Cláudio Francisco Brogni ${ }^{1}$, Anderson Fernando de Souza ${ }^{2, *}$
}

\author{
${ }^{1}$ Department of Veterinary Medicine, Agroveterinary Sciences Center, Santa Catarina State University, Lages, \\ SC, Brazil \\ ${ }^{2}$ Department of Surgery, School of Veterinary Medicine and Animal Science, University of São Paulo, São \\ Paulo, SP, Brazil \\ *Correspondence: anderson.sji@hotmail.com; Tel.: +55 11 97594-1962
}

How to cite this paper: Brogni, C. F., \& Souza, A. F. de. (2021). Ultrasonography in Sheep Follicular Dynamics. Open Journal of Agricultural Research, 1(1), 25-29. Retrieved from https://www.scipublications.com/journal/index.php/ojar/article/view/82

Received: June 9, 2021

Accepted: July 21, 2021

Published: July 22, 2021

Copyright: (C) 2021 by the authors. Submitted for possible open access publication under the terms and conditions of the Creative Commons Attribution (CC BY) license (http://creativecommons.org/licenses /by/4.0/).

\begin{abstract}
The first visualizations of the structures of the sheep's reproductive system, whether of the uterus or ovaries, were performed through exploratory laparotomies, laparoscopies or through materials obtained in slaughterhouse, being possible to evaluate only what was happening at that moment in the estrous cycle. With the emergence of ultrasound from the 90 s, it became possible to dynamically monitor what happened at each moment of the estrous cycle at different times of the year, without having to slaughter the females. Because it is a non-invasive technique and the stress caused by its use is very low, it is increasingly necessary to use ultrasound in sheep, either for pregnancy diagnosis or for multiplying herds using biotechnologies, which the ultrasound examination becomes indispensable to obtain the best results. This review aims to describe the main advances in the study of the estrous cycle of sheep with the help of ultrasonography and its influence on the productive efficiency of the herd.
\end{abstract}

Keywords: Estrous cycle; Follicular growth; Transrectal ultrasound; Ovine

\section{Introduction}

The reproductive management of sheep, with the use of the synchronization of the sheep, is a widely used technique, having an important role in the increase of productivity and in the technification of the herd. The synchronization of estrus has as main objectives to concentrate the calving in desirable times. This technique has been improved through studies of follicular dynamics, which after the advent of ultrasonography; it was possible to obtain a better understanding of the physiological mechanisms of sheep reproduction. Ovarian activity with the use of ultrasonography has been studied in several domestic females. Works developed in the last decades in domestic species [1-3], have contributed to a better understanding of several reproductive events.

Follicular dynamics in sheep started to be studied by ultrasonography from the 90's, where it became possible to better understand the functioning of ovarian structures, in each situation [4]. With ultrasound, it was possible to determine the number of waves and the emergence moments of each wave, and ovulation at the end of the estrous cycle. Previously, these assessments were performed by laparoscopy or laparotomy, at specific moments [5].

In addition, other techniques can be associated to better understand what is observed in ultrasound, such as the plasma hormonal concentration, which helps in understanding the functionality of structures mapped by ultrasound [6,7]. Demonstrating whether an ovarian cyst is functional or functional, whether the follicle is releasing estrogen or not, or even the actual plasma hormonal concentration, after the application of some exogenous hormone. This tool set has been used to better understand the events related to follicular dynamics in sheep. 


\section{Estrous cycle}

The estrous cycle is a set of events that happen successively in a known period. In sheep, on average, the interval between these cycles is $17 \pm 2$ days, and they are divided into two phases, the luteal phase, starting on day 2 (estrus = day 0 ) until the 13th day of the cycle and in the follicular phase of 14th day until ovulation. The estrous cycles have an average duration of 17 days, varying from 14 to 19, regardless of the animal's origin. However, the duration of heat is variable between 24 to 36 hours in tropical breeds and about 45 hours, varying from 12 to 72 hours, in temperate climate breeds

\section{Endocrine regulation of the estrous cycle and follicular dynamics}

Estrous cycles are associated with numerous changes in the neuroendocrine system and depend on coordinated interactions between organs. The central nervous system, by the action of the gonadotropin-releasing hormone $(\mathrm{GnRH})$, stimulates the adenohypophysis to the synthesis and secretion of the luteinizing hormones (LH) and stimulating follicle (FSH). These pituitary gonadotropins stimulate the ovaries to synthesize the hormones progesterone and estrogen and together with them promote the development of ovarian follicles and ovulation [8]. The follicular phase begins when the plasma progesterone concentration decreases below $1 \mathrm{ng} / \mathrm{mL}$ [9] as a result of the action of uterine prostaglandin on the corpus luteum. In this way, the elevation of the plasma estrogen concentration occurs, determinant in the appearance of sexual behavior and in the increase of the frequency of the LH pulses. The secretion of LH, in turn, when estrus is started, increases until reaching a pre-ovulatory discharge. The peak duration varies between 8 and 12 hours and ovulation occurs 24 hours after the LH peak [10].

After ovulation, the luteal phase of the estrous cycle begins. This phase corresponds to $80 \%$ of the cycle and will end with the lysis of the corpus luteum by the release of uterine prostaglandin (PGF2 $\alpha$ ). The corpus luteum present in this phase is responsible for the release of progesterone; it is formed by the luteinization of the granulosa cells of the ovulatory follicle. The corpus luteum is made up of large cells, derived from granulosa, larger progesterone producers and insensitive to LH pulses, and small cells, derived from teak, little progesterone producing, but sensitive to LH [11]. With the development of the corpus luteum, the plasma level of progesterone secreted by it increases [12] and reaches a plateau on the eighth day of the cycle at a concentration of $3-4 \mathrm{ng} / \mathrm{mL}$ [8].

In the luteal phase, ovarian follicles emerge because the FSH concentration is increasing. Progesterone in this period is elevated, thus decreasing the frequency of release of $\mathrm{LH}$ pulses, the larger follicles that depend on this hormone regress and a new follicular emergence begins. This pattern of follicular growth and regression is known as follicular waves, observed both in the reproductive season $[3,13]$ and in the seasonal anestrus $[1,14]$. Follicular growth patterns emerge at intervals of 4 to 6 days, with three more follicular waves per cycle $[12,15]$.

\section{Ultrasonography in sheep: Practical applications}

The first studies to understand what happened during the estrous cycle of sheep were carried out by exploratory laparotomies, laparoscopies or through materials obtained in refrigerators [16-18]. Although some information acquired by these means is contradictory, the first statements about the follicular development of sheep following a wave growth pattern was made in 1973 [18]. The confirmation of this observation would happen later, in the 90's with the incorporation of transrectal ultrasound $[2,19,20]$ promoting great advances in the knowledge of the reproductive physiology of this species. 
Transrectal ultrasound is a non-invasive technique that has been used for the frequent monitoring of morphological changes in the reproductive organs of conscious animals, in season and with minimal stress. The use of ultrasound allowed us to better understand the endocrine control of antral follicles in development throughout the estrous cycle, as well as the ovarian effects of various exocrine hormonal treatments in sheep [21]. The ultrasound image is formed by the reflection and dispersion of high frequency ultrasound pulses through acoustic tissue interfaces. Different tissue densities cause different reflections; wide, smooth interfaces are generally brighter than smaller interfaces [22]. Vinoles et al. [23] concluded that transrectal ultrasound is an accurate method for estimating the size and number of luteal bodies and ovarian follicles in sheep.

Invariably at some point in monitoring follicle population dynamics, there may be difficulty in visualizing the ovaries or they appear to be inverted. To get around this, some procedures can improve the position of the ovary. Karen et al. [24] describes that raising the sheep's belly as if it were a hug, or that the use of a trunk with a platform, where the sheep is positioned on a platform in an attempt to move the uterus back and allow ovarian visualization, and that still the trotting of these sheep, in order to move the intestinal loops in front of the ovaries, can be quite effective alternatives for the best location and visualization of the ovaries.

In addition, the use of ultrasound in superovulation programs becomes increasingly important, since varied results are found. It is believed that this amplitude in the results of superovulation occurs when basically taking into account the estrous cycle as a starting point [25]. It is necessary to obtain solid knowledge about the biological phenomenon of follicular dynamics [13], highlighting the moments of emergence of follicular waves, which can be directly assessed with the use of ultrasound.

\section{Ovarian ultrasound assessment methods}

For the actual monitoring of follicular dynamics, ultrasound observations should be performed from the beginning of the estrous cycle until the end of it. The visualization occurs between one and two times a day from the moment of estrus and when approaching ovulation, the interval of observations is shortened to 8 hours, allowing the evaluation of ovulatory moments. Ovulation is defined by the absence of the dominant follicle, which was detected in previous ultrasound exams [22].

For better observation of ovarian structures, females are handled in a quadrupedal position, with the abdominal wall compressed, to facilitate the visualization of the uterus and ovaries. The ultrasound equipment is used in real-time B-mode, using a linear rectal transducer with frequencies ranging from 6 to $8 \mathrm{MHz}$, coupled to a slightly curved plastic tube (length $30 \mathrm{~cm}$ ) to allow its handling externally. Firstly, it is necessary to remove the feces from the rectum and then deposit the gel inside the vaginal canal and on the transducer, for better observation of the structures. To help locate the ovaries, some maneuvers are necessary. When the urinary bladder is passed, the uterine horns are located on its side, so the transducer must be rotated left and right in order to observe the ovaries and their structures, and that each evaluation must be performed on a card exclusive to each female to ensure consistent results in ultrasound assessments of follicular dynamics.

\section{Conclusion}

Ultrasound is a widely used non-invasive technique in sheep that brings extremely reliable results. The use of this technique allows a better understanding of the functioning of the estrous cycle by correctly identifying the number of waves of each animal, the moment of ovulation, and differences between the cyclicity, transition and anestrous periods. However, for use in follicular dynamics, the veterinary professional must be well trained 
to obtain real results regarding the position of the same follicle in different observations during the estrous cycle.

Difficulties was encountered in the location and visualization of the ovaries, which can be overcome with some management maneuvers. The ultrasound technique must be widely used, since it is possible to obtain several responses on follicular dynamics in sheep without causing damage to them.

Author Contributions: Conceptualization, $\mathrm{CFB}$; writing - original draft preparation, $\mathrm{CFB}$ and AFS; writing - review and editing, CFB and AFS. All authors have read and agreed to the published version of the manuscript."

Funding: This research received no external funding.

Conflicts of Interest: The authors declare no conflict of interest.

\section{References}

[1] Bartlewski, P.M.; Beard, A.P.; Cook, S.J.; Rawlings, N.C. Ovarian Follicular Dynamics during Anoestrus in Ewes. Reproduction 1998, 113, 275-285, doi:10.1530/jrf.0.1130275.

[2] Ginther, O.J.; Kot, K.; Wiltbank, M.C. Associations between Emergence of Follicular Waves and Fluctuations in FSH Concentrations during the Estrous Cycle in Ewes. Theriogenology 1995, 43, 689-703, doi:10.1016/0093-691x(94)00074-5.

[3] Ginther, O.J.; Kot, K. Follicular Dynamics during the Ovulatory Season in Goats. Theriogenology 1994, 42, 987-1001, doi:10.1016/0093-691X(94)90121-X.

[4] Menchaca, A.; Rubianes, E. New Treatments Associated with Timed Artificial Insemination in Small Ruminants. Reprod Fertil Dev 2004, 16, 403-413, doi:10.10371/RD04037.

[5] Boscos, C.M.; Samartzi, F.C.; Dellis, S.; Rogge, A.; Stefanakis, A.; Krambovitis, E. Use of Progestagen-Gonadotrophin Treatments in Estrus Synchronization of Sheep. Theriogenology 2002, 58, 1261-1272, doi:10.1016/S0093-691X(02)01040-3.

[6] Vilariño, M.; Rubianes, E.; Menchaca, A. Re-Use of Intravaginal Progesterone Devices Associated with the Short-Term Protocol for Timed Artificial Insemination in Goats. Theriogenology 2011, 75, 1195-1200, doi:10.1016/j.theriogenology.2010.11.030.

[7] Vilariño, M.; Rubianes, E.; van Lier, E.; Menchaca, A. Serum Progesterone Concentrations, Follicular Development and Time of Ovulation Using a New Progesterone Releasing Device (DICO®) in Sheep. Small Ruminant Research 2010, 91, 219-224, doi:10.1016/j.smallrumres.2010.02.014.

[8] Morello, H.H.; Chemineau, P. Características anatômicas e funcionais do sistema reprodutor da fêmea. In Reprodução ovina e caprina; Aisen, E.G., Ed.; MedVet: São Paulo, 2008; pp. 11-15.

[9] Souza, M.I.L.; Uribe-Velásquez, L.F.; Oba, E.; Filho, O.G. de S.; Ramos, A. de A. Secreção de esteróides ovarianos, em ovelhas mestiças de raças exploradas para corte, em distintos momentos reprodutivos, no Estado de São Paulo. Ciênc. anim. bras. 2008, 9, 1107-1113.

[10] Cumming, I.A.; Brown, J.M.; Blockey, M.A.; Goding, J.R. Regulation of the Oestrous Cycle in the Ewe. J Reprod Fertil 1971, 24, 148-149, doi:10.1530/jrf.0.0240148.

[11] Sangha, G.K.; Sharma, R.K.; Guraya, S.S. Biology of Corpus Luteum in Small Ruminants. Small Ruminant Research 2002, 43, 5364, doi:10.1016/S0921-4488(01)00255-3.

[12] Viñoles, C.; Forsberg, M.; Rubianes, E. Ovarian Follicular Dynamics during the Estrous Cycle in the Ewe. In Proceedings of the International Congress on Animal Reproduction; Estocolmo, 2000; Vol. 14, pp. 26-30.

[13] Evans, A.C.O.; Duffy, P.; Hynes, N.; Boland, M.P. Waves of Follicle Development during the Estrous Cycle in Sheep. Theriogenology 2000, 53, 699-715, doi:10.1016/S0093-691X(99)00268-X.

[14] Souza, C.J.H.; Campbell, B.K.; Baird, D.T. Follicular Dynamics and Ovarian Steroid Secretion in Sheep during Anoestrus. Reproduction 1996, 108, 101-106, doi:10.1530/jrf.0.1080101.

[15] Leyva, V.; Buckrell, B.C.; Walton, J.S. Regulation of Follicular Activity and Ovulation in Ewes by Exogenous Progestagen. Theriogenology 1998, 50, 395-416, doi:10.1016/S0093-691X(98)00148-4.

[16] Noel, B.; Bister, J.L.; Paquay, R. Ovarian Follicular Dynamics in Suffolk Ewes at Different Periods of the Year. Reproduction 1993, 99, 695-700, doi:10.1530/jrf.0.0990695.

[17] Driancourt, M.A.; Gibson, W.R.; Cahill, L.P. Follicular dynamics throughout the oestrous cycle in sheep. A review. Reprod. Nutr. Dévelop. 1985, 25, 1-15, doi:10.1051/rnd:19850101.

[18] Brand, A.; Jong, W.H.R. de Qualitative and Quantitative Micromorphological Investigations of the Tertiary Follicle Population during the Oestrous Cycle in Sheep. Reproduction 1973, 33, 431-439, doi:10.1530/jrf.0.0330431.

[19] Ravindra, J.P.; Rawlings, N.C.; Evans, A.C.O.; Adams, G.P. Ultrasonographic Study of Ovarian Follicular Dynamics in Ewes during the Oestrous Cycle. Reproduction 1994, 101, 501-509, doi:10.1530/jrf.0.1010501. 
[20] Rubianes, E.; Castro, T. de; Carbajal, B. Effect of High Progesterone Levels during the Growing Phase of the Dominant Follicle of Wave 1 in Ultrasonically Monitored Ewes. Canadian Journal of Animal Science 1996, 76, 473-475, doi:10.4141/cjas96-071.

[21] Wu, D.; Barrett, D.M.W.; Rawlings, N.C.; Giffin, J.L.; Bartlewski, P.M. Relationships of Changes in Ultrasonographic Image Attributes to Ovulatory and Steroidogenic Capacity of Large Antral Follicles in Sheep. Animal Reproduction Science 2009, 116, 7384, doi:10.1016/j.anireprosci.2009.01.011.

[22] Liu, X.; Dai, Q.; Hart, E.J.; Barrett, D.M.W.; Rawlings, N.C.; Pierson, R.A.; Bartlewski, P.M. Ultrasonographic Characteristics of Ovulatory Follicles and Associated Endocrine Changes in Cyclic Ewes Treated with Medroxyprogesterone Acetate (MAP)-Releasing Intravaginal Sponges and Equine Chorionic Gonadotropin (ECG). Reproduction in Domestic Animals 2007, 42, 393-401, doi:10.1111/j.1439-0531.2006.00798.x.

[23] Viñoles, C.; Meikle, A.; Forsberg, M. Accuracy of Evaluation of Ovarian Structures by Transrectal Ultrasonography in Ewes. Animal Reproduction Science 2004, 80, 69-79, doi:10.1016/S0378-4320(03)00141-6.

[24] Karen, A.; Szabados, K.; Reiczigel, J.; Beckers, J.-F.; Szenci, O. Accuracy of Transrectal Ultrasonography for Determination of Pregnancy in Sheep: Effect of Fasting and Handling of the Animals. Theriogenology 2004, 61, 1291-1298, doi:10.1016/j.theriogenology.2003.07.018.

[25] Cognie, Y. State of the Art in Sheep-Goat Embryo Transfer. Theriogenology 1999, 51, 105-116, doi:10.1016/S0093-691X(98)00235-0. 